\title{
The Impact of the Presumption of Innocence on Indicted Public Officeholders
}

\author{
Rinat KitaiSangero, \\ Zefat Academic College
}

\begin{abstract}
Although the presumption of innocence is widely recognized as a fundamental principle of criminal and constitutional law, its implications are disputed. The presentation would consider the implication of the presumption of innocence in administrative proceedings concerning the removal of indicted public officeholders from their position and would relate to the holding of the Israeli Supreme Court regarding the possibility of assigning Benjamin Netanyahu, the indicted Israeli Prime Minister of the outgoing government, with the task of forming a government. The presentation would argue that a broad view of the presumption of innocence should protect accused persons from the infliction of any kind of harm by the state which expresses guilt towards them based on their status as accused, and should lead to its applicability to administrative proceedings concerning the removal of public officeholders from their position.
\end{abstract}

Keywords: The presumption of innocence; indicted public officeholders. 